\title{
DEVELOPMENT OF ETHNOMATHEMATICS-BASED WORKSHEET ON TRANSFORMATION GEOMETRY
}

\author{
Ratu Sarah Fauziah Iskandar ${ }^{1}$, Dewi Ranti ${ }^{2}$, Nanang Priatna ${ }^{3}$ \\ ${ }^{1}$ Universitas Muhammadiyah Tangerang, Jln. Perintis Kemerdekan I/33, Tangerang, Indonesia \\ ${ }^{2}$ SMK Negeri 5 Bekasi,Villa Indah Permai Blok E27, Bekasi, Indonesia \\ ${ }^{3}$ Universitas Pendidikan Indonesia, Jln. Setiabudhi No. 229 Bandung, Indonesia \\ e-mail: ratusarah@upi.edu
}

\begin{abstract}
Examining the efficacy of West Java batik-themed student worksheets in addressing students' math problems is the goal of this study. As a quantitative study, this study relies solely on post-test control design. All pupils in class XI of SMK Negeri 5 Bekasi were included in this study. Cluster random sampling was the method employed in this investigation. The findings of the sampling revealed that the experimental class and the control class were both made up of two classes. The experimental class employs ethnomathematics-based mathematics teaching materials, whereas the control class does not use ethnomathematics-based mathematics teaching materials in their education. The methods of documenting, observation, and testing are all utilized in the data collection process. The quantitative data analysis approach employed in this study is the t-test. It is possible to draw inferences based on these findings, which are based on the outcomes of posttest data for the two classes, which are the control class and the experimental class, which show that the 2-way significant value (t-tailed) is 0.0000.05. As a result, the experimental group differs significantly from the control group.
\end{abstract}

Keywords: Development of teaching materials, ethnomathematics, transformasi geometry

\begin{abstract}
Abstrak
Tujuan dari penelitian ini adalah menguji keefektifan LKS bertema batik Jawa Barat dalam mengatasi masalah matematika siswa. Sebagai penelitian kuantitatif, penelitian ini hanya mengandalkan desain kontrol post-test. Semua siswa kelas XI SMK Negeri 5 Bekasi diikutsertakan dalam penelitian ini. Cluster random sampling adalah metode yang digunakan dalam penelitian ini. Hasil sampling menunjukkan bahwa kelas eksperimen dan kelas kontrol sama-sama terdiri dari dua kelas. Kelas eksperimen menggunakan bahan ajar matematika berbasis etnomatematika, sedangkan kelas kontrol tidak menggunakan bahan ajar matematika berbasis etnomatematika dalam pendidikannya. Metode pendokumentasian, observasi, dan pengujian semuanya digunakan dalam proses pengumpulan data. Pendekatan analisis data kuantitatif yang digunakan dalam penelitian ini adalah uji-t. Berdasarkan temuan tersebut dapat ditarik kesimpulan, yaitu berdasarkan hasil data posttest untuk kedua kelas, yaitu kelas kontrol dan kelas eksperimen, yang menunjukkan bahwa nilai signifikansi 2 arah ( $t$-tailed) adalah $0,0000,05$. Akibatnya, kelompok eksperimen berbeda secara signifikan dari kelompok kontrol.
\end{abstract}

Kata kunci: pengembangan bahan ajar, etnomateamatika, transformasi geometri

\section{INTRODUCTION}

The quality of human resources must be addressed in order to improve education. As a result, it is imperative that educational reform be pursued on a regular basis. One of the most valuable courses in everyday life, math is essential for kids to understand. Vocational high school students, for example, study mathematics. Due to the material's abstract nature, vocational high school students struggle to comprehend and solve the subject's mathematical problems (Setiany, 2011).

Many human activities are inadvertently influenced by mathematical phenomena Received: November 1, 2021; Revised: January 5, 2022; Accepted: January 27, 2022 
(Sembiring, 2010; Young, 2017). To put it another way, culture and mathematics are intertwined in a way that dates back to antiquity and is passed down from parent to child (Muhtadi, 2017).

the aforementioned Ardiyani (2018) At every grade level, mathematics is taught to foster students' ability to think critically and logically in order to solve problems that arise in their daily lives. In everyday life, humans utilize mathematics to measure distance, height and weight, read tables in newspapers and divide groups, calculate shopping prices, and more. To prepare pupils for real-world circumstances, math can be used efficiently.

Hadi (2005) asserts that pupils are not passive recipients of finished mathematics, but rather active participants. Therefore, pupils are required to enhance their critical thinking abilities through mathematics instruction, from elementary school through high school. One of the things the teacher pays attention to is the student's mathematical learning outcomes, given the importance of mathematics.

According to Ardiyani et al. (2018), there are other elements that can have an impact on math learning results. It is important to pay attention to what students are doing while they are studying. Contextual learning, according to Muslimin (2020), allows students to make connections between what they learn in school and what they learn in the real world. Their perspective is widened by contextual knowledge. This is due to the fact that exposing kids to novel situations might stimulate the formation of new neural networks in their brains. Thus, students are empowered to discover and create meaning on their own.

Observations of grade $\mathrm{XI}$ instructors at SMKN 5 Bekasi show that the level of mathematical mastery among grade XI pupils is woefully low. Numerous reasons contribute to this, among them a lack of enthusiasm for mathematical education. This is due to students' perceptions of mathematics education as being more difficult and intimidating than it actually is. in addition to the epidemic situation that prevents students from engaging actively with information sources, namely teachers. Math teachers have used a variety of methods, such as switching from lecture mode to interactive media, persuasion, and more, to pique students' interest in the subject.

Anthropologists came up with the concept of ethnomathematics, which is the study of mathematics as it applies to everyday life. Anastasiyas, and others (2017) It is hoped that culture-based mathematics learning will be an alternate method of implementing 
educational innovation that is carried out in accordance with the local wisdom of the local school in order to improve student outcomes. Rdht (2019) Mathematical features of a particular culture or group are investigated via the lens of ethnomathematics. Research in ethnomathematics holds a lot of promise for an Indonesian culture as large and diverse as Indonesia's.

As a country with a wide range of cultures, Indonesia has a unique chance to improve the mathematics education system in Indonesia by bringing mathematics closer to students' daily lives (Zulkardi, 2002; Abdullah, 2017). Students find it easier to understand mathematics because of the connection between ethnomatematics and multiculturalism. To represent the mathematical practices of identified cultural groups, D'Ambrosio invent ed the word ethnomathematics (Rosa \& Orey, 2011). It may be seen as the study of mathematical ideas in any culture. Among the goals of D'Ambrosio's ethnomathematics program is to recognize that there are different ways of doing mathematics by examining the appropriation of academic mathematical knowledge by different sectors of society and by examining different modes in which cultures negotiate their mathematical practices.

The use of ethnomathematics as a technique of energizing and exciting pupils is intended to address issues of saturation and difficulty learning. Ethnomathematics may recognize and apply inter-mathematical idea connections in solving an issue when it is used in learning mathematics. Ethnomatematics is a method of teaching mathematics that ties it to the culture of the place where it is taught (Zaenuri, et al: 2020). Examining the efficacy of West Java batik-themed student worksheets in addressing students' math problems is the goal of this study.

\section{METHODS}

As a quantitative study, this study relies solely on post-test control design. All pupils in class XI of SMK Negeri 5 Bekasi were included in this study. Cluster random sampling was the method employed in this investigation. The findings of the sampling revealed that the experimental class and the control class were both made up of two classes. The experimental class employs ethnomathematics-based mathematics teaching materials, whereas the control class does not use ethnomathematics-based mathematics teaching materials in their education. The methods of documenting, observation, and testing are all utilized in the data 
collection process. The quantitative data analysis approach employed in this study is the ttest.

\section{RESULTS AND DISCUSSION}

Teaching resources based on ethnomathematics are a collection of materials and math problems that are linked to the local culture and contextual issues in the field. At the end of the day, Prahmana (2020) It is possible to use this culture as a means of exploring mathematical principles in order to bring mathematics closer to the reality and perspective of its people.
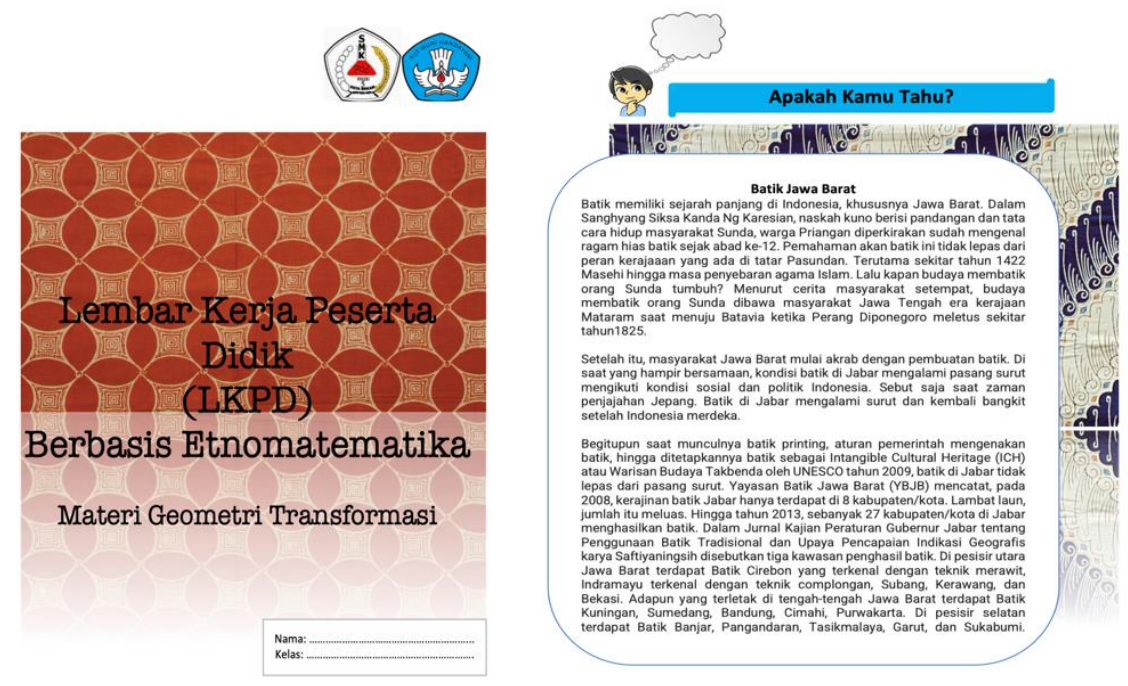

Figure. 1. Layout of Ethnomatics-Based Worksheet

Ethnomathematics-based worksheet features West Java's Batik Megamendung, as illustrated in the graphic above. Using the Batik Megamendung, it can be deduced that it is a substance that deals with geometric transformations such as rotation and translation. Students will be more motivated to learn mathematics if the subject is linked to the culture in which they live. 

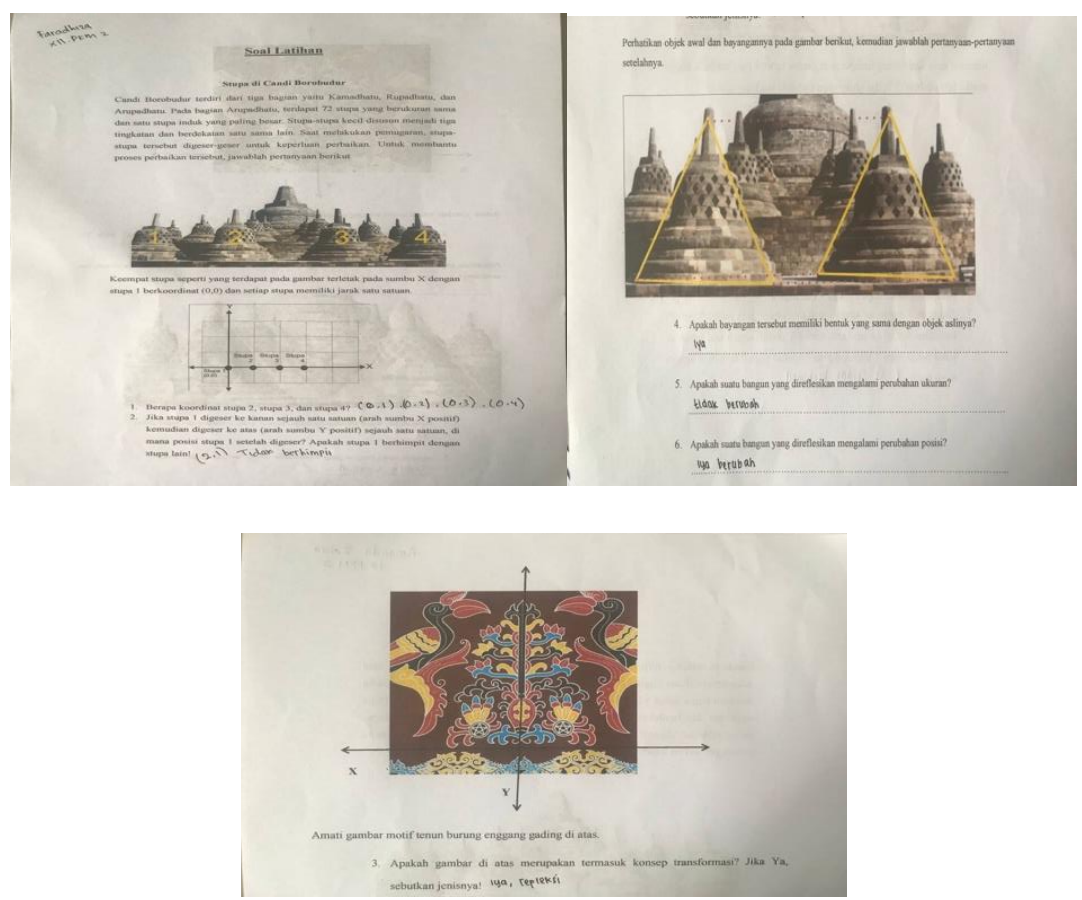

Figure. 2. One of the Student Test Results

The experimental class received the lowest score of 80 and the maximum score of 100 on the posttest data supplied to the experimental and control classes after learning. The control group, on the other hand, scored as low as 60 and as high as 80 . The following results were derived from the final test results of students in the experimental and control classes.

Table. 1. Normality Test Results

\begin{tabular}{|l|l|r|r|r|r|r|r|}
\hline \multicolumn{1}{|c|}{ Tests of Normality } \\
\hline & \multirow{2}{*}{} & \multicolumn{2}{|c|}{ Kolmogorov-Smirnova } & \multicolumn{3}{c|}{ Shapiro-Wilk } \\
\cline { 2 - 8 } & Kelas & Statistic & df & \multicolumn{1}{c|}{ Sig. } & Statistic & df & \multicolumn{1}{c|}{ Sig. } \\
\hline Hasil & Kelas A & .167 & 18 & .198 & .900 & 18 & .058 \\
\cline { 2 - 8 } $\begin{array}{l}\text { Belajar } \\
\text { Siswa }\end{array}$ & Kelas B & .252 & 16 & .008 & .834 & 16 & .008 \\
\hline
\end{tabular}

a. Lilliefors Significance Correction

A 0.058 significance level is greater than 0.05 according to the SPSS output table. Data is normally distributed if the Shapiro-Wilk normality test is used as the basis for decisionmaking. 
Table. 2. Homogeneity Test Result

\begin{tabular}{|l|l|r|r|r|r|}
\hline \multicolumn{7}{|c|}{ Test of Homogeneity of Variance } \\
\hline \multirow{3}{*}{ Hasil Belajar Siswa } & Levene Statistic & df1 & df2 & \multicolumn{1}{c|}{ Sig. } \\
\cline { 2 - 6 } & Based on Mean & 3.838 & 1 & 32 & .059 \\
\cline { 2 - 6 } & Based on Median & 3.707 & 1 & 32 & .063 \\
\cline { 2 - 6 } & $\begin{array}{l}\text { Based on Median and with } \\
\text { adjusted df }\end{array}$ & 3.707 & 1 & 26.689 & .065 \\
\cline { 2 - 7 } & Based on trimmed mean & 4.005 & 1 & 32 & .054 \\
\hline
\end{tabular}

Sig. Levene's Test for Equality of Variances for the variable of mathematics learning outcomes has a value of 0.059 based on the above output. This means that the data variance of arithmetic learning outcomes in experimental and control class pupils is homogeneous because $0.059>0.05$.

Table. 3. T-Test Difference Test Results

\begin{tabular}{|c|c|c|c|c|c|c|c|c|c|c|}
\hline \multicolumn{11}{|c|}{ Independent Samples Test } \\
\hline & & \multicolumn{2}{|c|}{$\begin{array}{l}\text { Levene's } \\
\text { Test for } \\
\text { Equality of } \\
\text { Variances }\end{array}$} & \multicolumn{7}{|c|}{ t-test for Equality of Means } \\
\hline & & \multirow[b]{2}{*}{$\mathrm{F}$} & \multirow[b]{2}{*}{ Sig. } & \multirow[b]{2}{*}{$\mathrm{t}$} & \multirow[b]{2}{*}{$\mathrm{df}$} & \multirow{2}{*}{$\begin{array}{l}\text { Sig. (2- } \\
\text { tailed) }\end{array}$} & \multirow{2}{*}{$\begin{array}{c}\text { Mean } \\
\text { Difference }\end{array}$} & \multirow{2}{*}{$\begin{array}{l}\text { Std. Error } \\
\text { Difference }\end{array}$} & \multicolumn{2}{|c|}{$\begin{array}{c}95 \% \text { Confidence } \\
\text { Interval of the } \\
\text { Difference }\end{array}$} \\
\hline & & & & & & & & & Lower & Upper \\
\hline \multirow{2}{*}{$\begin{array}{l}\text { Hasil } \\
\text { Belajar } \\
\text { Siswa }\end{array}$} & $\begin{array}{l}\text { Equal variances } \\
\text { assumed }\end{array}$ & 3.838 & .059 & 6.340 & 32 & .000 & 18.81944 & 2.96827 & 12.77328 & 24.86561 \\
\hline & $\begin{array}{l}\text { Equal variances } \\
\text { not assumed }\end{array}$ & & & 6.517 & 28.600 & .000 & 18.81944 & 2.88759 & 12.91008 & 24.72881 \\
\hline
\end{tabular}

T-test results utilizing the SPSS gadget at a significance level of 0.05 demonstrated that the experimental class students' learning outcomes were not significantly different from those of the control class students. The results of the independent sample t test analysis may be seen in the table above. The significant value for the 2 -way (t-tailed) analysis is 0.0000 .05 , as can be shown. As a result, the experimental group differs significantly from the control 
group. Ethnomathematics-based math teaching materials were found to have a higher descriptive value than traditional math teaching materials.

\section{CONCLUSION}

It is possible to draw inferences based on these findings, which are based on the outcomes of posttest data for the two classes, which are the control class and the experimental class, which show that the 2 -way significant value (t-tailed) is 0.0000 .05 . As a result, the experimental group differs significantly from the control group. Ethnomathematics-based mathematics was found to be used in the treatment group.

\section{ACKNOWLEDGMENTS}

Recognize those who helped in the research, especially funding supporters of your research. Include individuals who have assisted you in your study: Advisors, Financial supporters, or may other supporters, i.e., Proofreaders, Typists, and Suppliers who may have given materials.

\section{REFERENCES}

Abdullah, A. S. (2017). Ethnomathematics in perspective of Sundanese culture. Journal on Mathematics Education, 8(1), 1-16. https://doi.org/10.22342/jme.8.1.3877.1-16

Ardiyani, S. M., Gunarhadi, \& Riyadi. (2018). Realistic Mathematics Education in Cooperative Learning Viewed from Learning Activity. Journal on Mathematics Education, 9(2), 301310.

Astutiningtyas, E. L., Wulandari, A. A., \& Farahsanti, I. (2017). Etnomatematika Dan Pemecahan Masalah Kombinatorik. Jurnal Math Educator Nusantara (JMEN), 3(2), 111-118.

D'Ambrosio, U. (2001). What is ethnomathematics, and how can it help children in schools?,Teaching Children Mathematics, 7(6). 308-310.

Hadi, S. (2005). Pendidikan Matematika Realistik dan Implementasinya. Banjarmasin: Tulip.

Muhtadi, D., Sukirwan, Warsito, \& Prahmana, R.C.I. (2017). Sundanese Ethnomathematics: Mathematical Activities in Estimating, Measuring, and Making Patterns. Journal on Mathematics Education, 8(2), 185-198.

Muslimin, Putri, R.I.I., Zulkardi, \& Aisyah, N. (2020). Learning Integers with Realistic Mathematics Education Approach based on Islamic Values. Journal on Mathematics Education, 11(3), 363-384. http://doi.org/10.22342/jme.11.3.11721.363-384.

Prahmana, R. C. I \& D'ambrosio, U. (2020). Learning Geometry And Values From Patterns: Ethnomathematics On The Batik Patterns Of Yogyakarta, Indonesia. Journal On Mathematics Education, 11 (3), 439-456

Rosa, M. \& Orey, D. C. (2011). Ethnomathematics: the cultural aspects of mathematics. Revista Latinoamericana de Etnomatemática, 4(2), 32-54. 
Rudhito, A. A., Kristanto, Y. D. \& Melissa, M. M. (2019). Development Of Open Online Ethnomathematics Course. Journal Of Physics: Conference Series, Volume 1470, The 7th South East Asia Design Research International Conference (SEADRIC 2019) 25-27 July 2019, Yogyakarta, Indonesia.

Setiany, E. P. (2011). Penerapan Pendekatan Realistic Mathematics Education Pada Materi Sistem Persamaan Linear Dua Variabel Siswa SMK. Jurnal Pendidikan Tambusai, 2(6), 1727-1733.

Supriadi, S. (2019). Didactic Design of Sundanese Ethnomathematics Learning for Primary School Students. International Journal of Learning, Teaching and Educational Research Vol. 18, No. 11, pp. 154-175, November 2019. https://doi.org/10.26803/ijlter.18.11.9

Young, J.R. (2017). Technology integration in mathematics education: Examining the quality of meta-analytic research. International Journal on Emerging Mathematics Education, 1(1), 71-86.

Zaenuri, D Purwanti and M Asikin. (2020). Etnomathematics of batik motifs in problem based learning. Journal of Physics: Conference Series, Volume 1567, $6^{\text {th }}$ Intenational Conference on Mathematics, Science, and Education (ICMSE 2019), 9-10 October 2019, Semarang, Indonesia.

Zulkardi. (2002). Developing a learning environment on realistic mathematics education for Indonesian student teachers. Enschede: University of Twente. 